J. Nat. Hist. Mus. Vol. 30, 2016-18 209-220

\title{
Assessment of non timber forest products in Baghmara Buffer Zone Community Forest, Chitwan, Nepal
}

\author{
Udisha Danekhu, Rajeswar Shrestha², and Sanu Raja Maharjan ${ }^{1} \bowtie$ \\ ${ }^{1}$ Goldengate International College, Battisputali, Kathmandu, Nepal \\ ${ }^{2}$ Central Department of Environmental Science, Tribhuvan University, Kirtipur, Kathmandu, Nepal \\ botanysanu@hotmail.com
}

\begin{abstract}
Non-Timber Forest Products (NTFPs) are the forest products except timber used for various purposes from which economic status of the country can be increased through green growth based economy. The study was conducted in Baghmara Buffer Zone Community Forest for the inventory, to document various uses and find out the preferred NTFPs potential for economic development of Community Forest User Groups. Stratified random sampling was applied in which 50 quadrats of size $25 \mathrm{~m} \times 20 \mathrm{~m}$ for trees, 100 subplots of $10 \mathrm{~m} \times 10 \mathrm{~m}$ for shrubs and 200 small subplots of $1 \mathrm{~m} \times 1 \mathrm{~m}$ size for herbs and climbers were taken. Parameters like density, frequency, abundance, importance value index, diversity index, evenness index and dominance index were calculated to find out the ecological status of NTFPs. Questionnaire survey of 100 households was done for studying different uses and interview with 10 key informants were carried out to identify 10 most preferred NTFPs. Altogether, 109 NTFPs were enumerated. Trewia nudiflora, Clerodendrum viscosum, Imperata cylindrica and Mikania micrantha were dominant tree, shrub, and herb and climber species according to Importance value Index (IVI). There is significant difference in density of trees, shrubs, herbs and climbers between different sample quadrats i.e. $p$ value $<0.05$. NTFPs found were used for medicine, fodder, food, veterinary, dying, handicrafts, crop management, ornamental, insecticides, construction, beverage, piscicidal, religious and miscellaneous purposes. Calamus tenuis, Curcuma longa, Piper longum, Phyllanthus emblica, Asparagus racemosus, Terminalia bellirica, Terminalia chebula, Bauhinia variegata, Tinospora sinensis and Dryopteris cochleata were ten most preferred Non Timber Forest Products from matrix preference ranking.
\end{abstract}

Keywords: ecological parameters, inventory, use categories, matrix preference ranking, resource assessment,

\section{INTRODUCTION}

Biological resources from forest are likely the key sources of energy in all forms consumed by human beings for their survival (Khanal, 2006). Non Timber Forest Products (NTFPs) consist of goods of biological origin other than timber, derived from forests, other wooded land and trees outside forests (FAO, 1999). NTFPs can be classified according to their end use as described by FAO (1995) as food, fodder, medicine, perfume and cosmetic, dying and tanning, utensils and handicraft, construction material, ornamental and exudates. The diversity of products, mode of organic production, free from pesticides and chemical fertilizers, having high medicinal and aromatic properties are some of the comparative advantages of the NTFPs sector of Nepal (Keshari, 2007). 
NTFPs can provide important community needs for improved rural livelihood; contribute to household food security and nutrition; help generate additional employment and income; offer opportunities for enterprises and entrepreneurship; contribute local economy and support biodiversity and other conservation objectives (FAO, 1995). The sustainable harvesting has to be considered in these regards in order to address the enormous variations in terms of usage, plant form, life cycle and product type, while the methods of assessment and sustainable harvesting of NTFPs have to be site and product specific to address both the ecological and socio-economic considerations (Ojha et al., 2003). This study, therefore, is aimed to explore and identify NTFPs and analyze their management entities at BBZCF in pursuit of assessment and sustainable harvesting of NTFPS.

\section{MATERIALS AND METHODS}

\section{Study area}

Baghmara Buffer Zone Community Forest (BBZCF) is situated in close vicinity of Chitwan National Park. It is located in Bachhauli VDC and covers an area of 215 ha. (163 ha. was naturally regenerated through community efforts) (Sharma et al., 2012). It is located in between $27^{\circ} 34.78^{\prime}-$ $27^{\circ} 35.53^{\prime}$ northern latitude and $84^{\circ} 28.43^{\prime}-84^{\circ} 29.40^{\prime}$ eastern longitude in central lowland Nepal at an elevation of 200 to $250 \mathrm{~m}$ above sea level. BBZCF is rich in biodiversity and is popular tourist destination for elephant riding and nature walk. The Operation Plan of BBZCF has given high priority for developing tourism sector but nearly neglects the management of NTFPs available in the forest. This community forest constitutes $77.03 \%$ forest area, $22.78 \%$ grassland and $0.19 \%$ religious areas (BBZCF, 2013). The forest is divided into 8 blocks for management purpose. The CF is bordered by Budhi Rapti River and Khageri Khola in the north and west, Badrahani and Raptiriver in the south, private land in the east and Chitrasen BZCF lies in north.

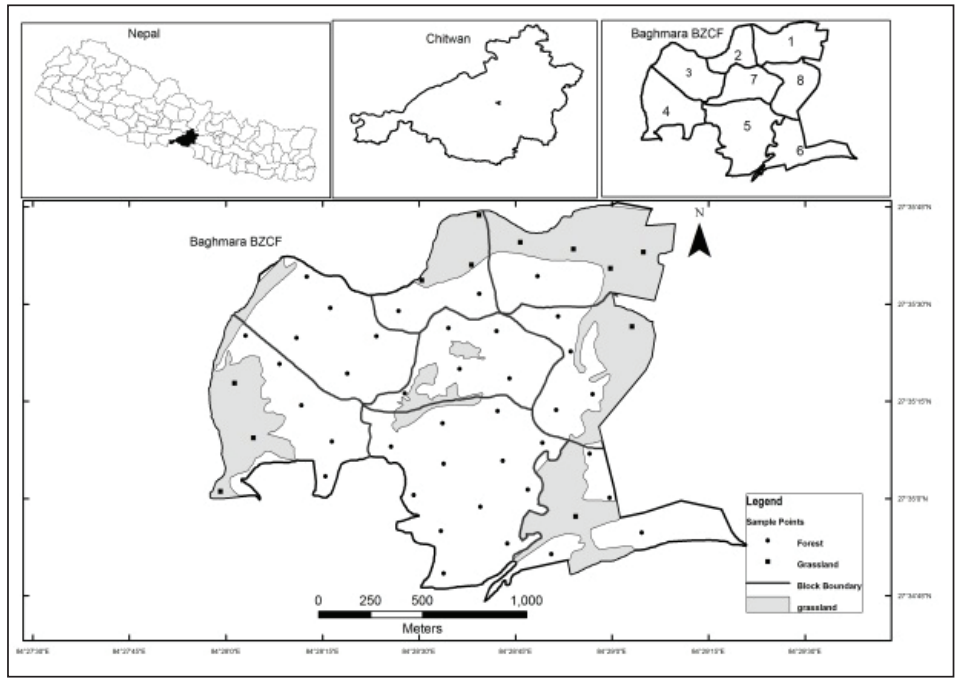

FIG. 1. Map of study area.

The study was exploratory as well as descriptive in nature. It included both qualitative and quantitative approaches via vegetation sampling and social survey. 


\section{Forest sampling for NTFPs resources assessment}

For inventory of NTFPs, stratified random sampling was applied with $1 \%$ sampling intensity in which the forest was divided into 8 blocks. The stratification was done according to the division of blocks done by Baghmara Buffer Zone Community forest for management purpose. For study of trees, 50 random quadrats of size $25 \mathrm{~m} \times 20 \mathrm{~m}$ were taken according to guideline given by MFSC (2004). 100 subplots of $10 \mathrm{~m} \times 10 \mathrm{~m}$ (2 diagonally opposite nesting plots in each tree sampling plot) were taken for study of shrubs and 200 micro plots of $1 \mathrm{~m} \times 1 \mathrm{~m}$ were laid for herbs/climber. Different parameters like Density, Frequency, Abundance, Importance Value Index, Diversity Index, Evenness Index and Dominance Index were calculated to find out the ecological status of NTFPs found.

Density $\quad=$ Total number of individuals of species

Total Number of quadrats studied $\times$ Area of quadrat taken

Frequency $=$ Number of quadrats in which species occurred $\times 100$

Total number of Quadrats studied

Abundance $=$ Total Number of individuals in all the sampling units

Total number of sampling units in which species occured

Abundance can also be recorded using the ACFOR scale which comprises of 5 classes as given in table 1.

TABLE 1. Classes of abundance.

\begin{tabular}{|l|l|}
\hline Value of abundance & Abundance class \\
\hline Above 90 & Abundant (a) or Dominant (d) \\
\hline $30-90$ & Common or Co-dominant (Co) \\
\hline $15-29$ & Frequent (f) \\
\hline $5-14$ & Occasional (o) \\
\hline $1-4$ & Rare (r) \\
\hline
\end{tabular}

Importance Value Index (IVI)

$\mid V I=$ Relative Density + Relative Frequency + Relative Abundance

Shannon-Wieners Diversity Index $\left(\mathrm{H}^{\prime}\right)$

$H^{\prime}=-\Sigma$ pi In pi

where, $p i=n_{i} / N, N=$ Total number of individual of all species, $n_{i}=$ no. of individuals of each species 
Evenness Index (e)

$\mathrm{e}=\mathrm{H}^{\prime}=/ \mathrm{InS}$,

where, $\mathrm{H}^{\prime}=$ = Shannon-Wiener's diversity index, $\mathrm{S}=$ Total number of species in the sample

Index of Dominance (D)

$\mathrm{D}=\sum(\mathbf{n i} / \mathbf{N})^{2}$

where, $\mathrm{ni}=$ number of individuals of each species, $\mathrm{N}=$ Total number of individual of all species

Morrisita's Similarity Index (Im)

Morrisita Index of Similarity $(\mathrm{Im})=\frac{2\left(\sum \mathrm{ni} 1 \times \mathrm{ni} 2\right)}{\left(\lambda_{1} \times \lambda_{2}\right)\left(\mathrm{N}_{1} \times \mathrm{N}_{2}\right)}$

where, $\mathrm{ni}=$ number of individuals of each species, $\mathrm{N}=$ Total number of individual of all species, $\lambda=$ Simpsons index of dominance.

Most of the species were identified in the field through local names with the help of local people and experts. The specimens of unidentified plants were collected; herbarium specimens were prepared and then identified at National Herbarium and Plant Laboratory (KATH). Valid scientific names with author citation were adopted according to the checklist Press et al. (2000).

\section{Household survey}

For social survey, 100 households especially indigenous group were surveyed using random sampling techniques for this open-ended questions were developed and used for survey. The minimum sample size for household survey was determined by using statistical formula given below (Arkin \& Colton. 1963) at 95\% confidence level.

Mathematically, $\mathrm{n}=\frac{\mathrm{NZ^{2 }} \times \mathrm{P}(1-\mathrm{p})}{\mathrm{Nd}^{2}+\mathrm{Z}^{2} \times \mathrm{P}(1-\mathrm{p})}$

where, $\mathrm{n}=$ sample size, $\mathrm{N}=$ Total number of households, $\mathrm{Z}=$ Confidence level (at $95 \%, \mathrm{z}$ =1.96), $P=$ Estimated population proportion (0.05), $d=$ Error limit of 5\% (0.05).

\section{Key informant survey}

10 key informant surveys were carried out with chairperson, members of the CFUGs, elderly person and local healers for getting more information on practices regarding NTFPs, availability, utility, present condition and situation of NTFPs species. Matrix preference ranking was done from key survey for identifying most preferred NTFPs.

\section{Matrix preference ranking}

The preference ranking of NTFPs available in the study area were carried out on the basis of various criteria of preference ranking form. 
TABLE 1. Preference ranking form.

\begin{tabular}{|c|c|c|c|c|}
\hline \multirow[t]{2}{*}{ S.N. } & \multirow[t]{2}{*}{ Criteria } & \multicolumn{3}{|c|}{ Scale and score } \\
\hline & & 3 & 2 & 1 \\
\hline 1. & Market demand & High & Moderate & Low \\
\hline 2. & Margin/Profit & High & Moderate & Low \\
\hline 3. & Availability (in time) & $\begin{array}{l}\text { Almost } \\
\text { always }\end{array}$ & Occasionally & Seasonal \\
\hline 4. & Availability (in space) & Widespread & Moderate & Low \\
\hline 5. & $\begin{array}{l}\text { Impact of harvesting on } \\
\text { survival of species }\end{array}$ & Minimum & Moderate & High \\
\hline 6. & $\begin{array}{l}\text { Amount of time needed to } \\
\text { find and harvest NTFPs }\end{array}$ & Short & Moderate & Long \\
\hline 7. & Regeneration potential & High & Moderate & Low \\
\hline 8. & Contribution to income & High & Moderate & Low \\
\hline 9. & Gender impact & Only women & $\begin{array}{l}\text { Both men and } \\
\text { women }\end{array}$ & Only men \\
\hline 10. & $\begin{array}{l}\text { Potential for employment } \\
\text { creation }\end{array}$ & High & Moderate & Low \\
\hline 11. & Processing technology & $\begin{array}{l}\text { Manual/Local } \\
\text { technology }\end{array}$ & $\begin{array}{l}\text { Mechanical/ } \\
\text { expertise }\end{array}$ & $\begin{array}{l}\text { Sophisticated/foreign } \\
\text { technology }\end{array}$ \\
\hline 12. & Uses & Diverse use & Medium use & Single use \\
\hline
\end{tabular}

Source: Thakur (2005), Magar (2008)

\section{RESULTS AND DISCUSSION}

\section{Inventory of NTFPs}

In the study, 109 different NTFP plant species were enumerated with 106 Angiosperm (85-Dicots and 21-Monocots) and 3 Pteridophytes which indicated that the area harbors variety of potential NTFPs. Herbs (47 species) were the most prominent life forms followed by trees ( 31 species), shrubs ( 24 species) and climbers ( 7 species). The total density of trees of BBZCF was found to be 300 trees/ha. Similarly density of shrubs, herbs and climbers were $5121 \mathrm{ind} . / \mathrm{ha}, 1044550 \mathrm{ind}$./ha and 14750 respectively. From the study, the dominant species with highest density in different life forms were- Trewia nudiflora among the tree species, Clerodendrum viscosum (shrub), Imperata cylindrica (herbaceous plant) and Mikania micrantha among climber species. There is significant difference in density of trees, shrubs, herbs and climbers between different quadrats i.e. $p<0.05$. Plants widespread with high frequency of occurrence values in different life forms were Trewia nudiflora, Callicarpa macrophylla, 
Dryopteris cochleata and Mikania micrantha. Similarly, the maximum abundance was found of Trewia nudiflora, Bambusa sp., Axonopus compressus and Piper longum (climber). On the basis of abundance values, 28 tree species were found rare and 3 as occasional. Among the shrub species, 8 were found rare, 8 occasional, 5 frequent and 3 common. Similarly, 5 species of herbs were rare, 15 occasional, 7 frequent, 6 common and 4 abundant or dominant and in climbers, 6 were rare and 1 occasional.

Trewia nudiflora was dominant tree with highest IVI value (103.33). Clerodendrum viscosum (73.93), Imperata cylindrica (43.10) and Mikania micrantha (138.55) were dominant species among shrubs, herbs and climbers on the basis of IVI values. The Dominance-Diversity (D-D) curves for all life forms were found consistent with normal distribution model of Preston (1948). The more steep curve of tree species than other life forms indicated the high dominance of a species i.e. Trewia nudiflora.

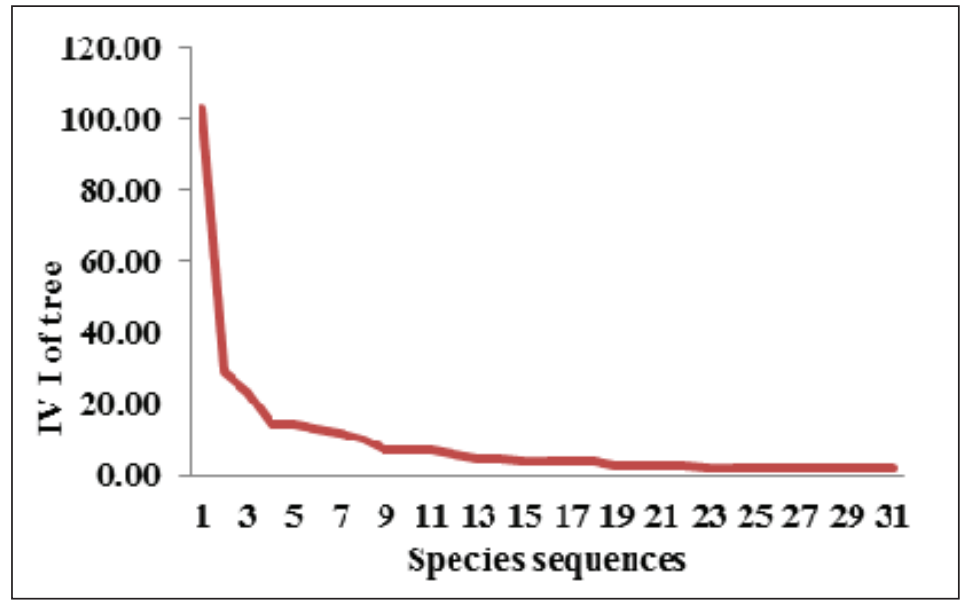

FIG. 2. Dominance-Diversity curve of trees.

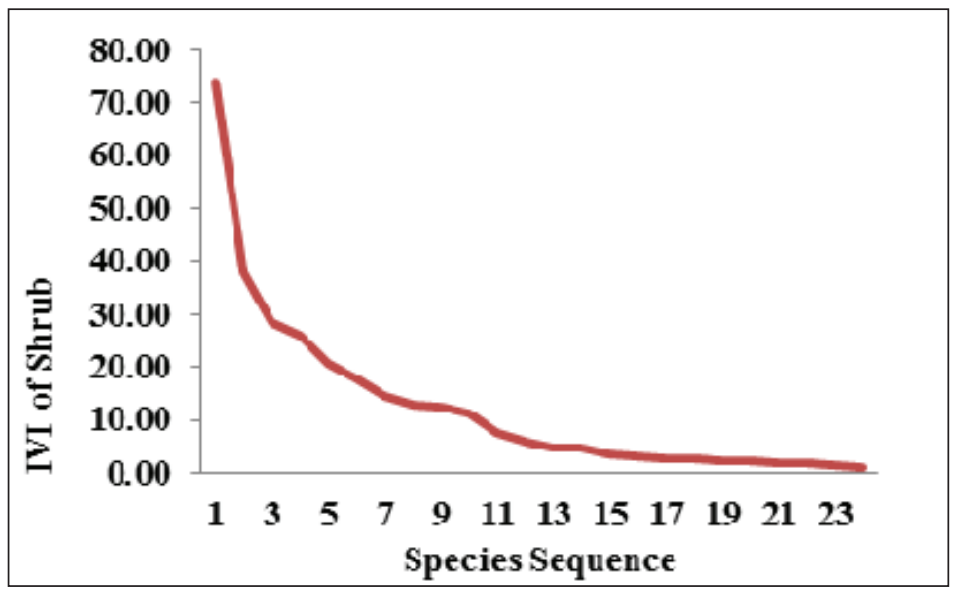

FIG. 3. Dominance-diversity curve of shrubs. 


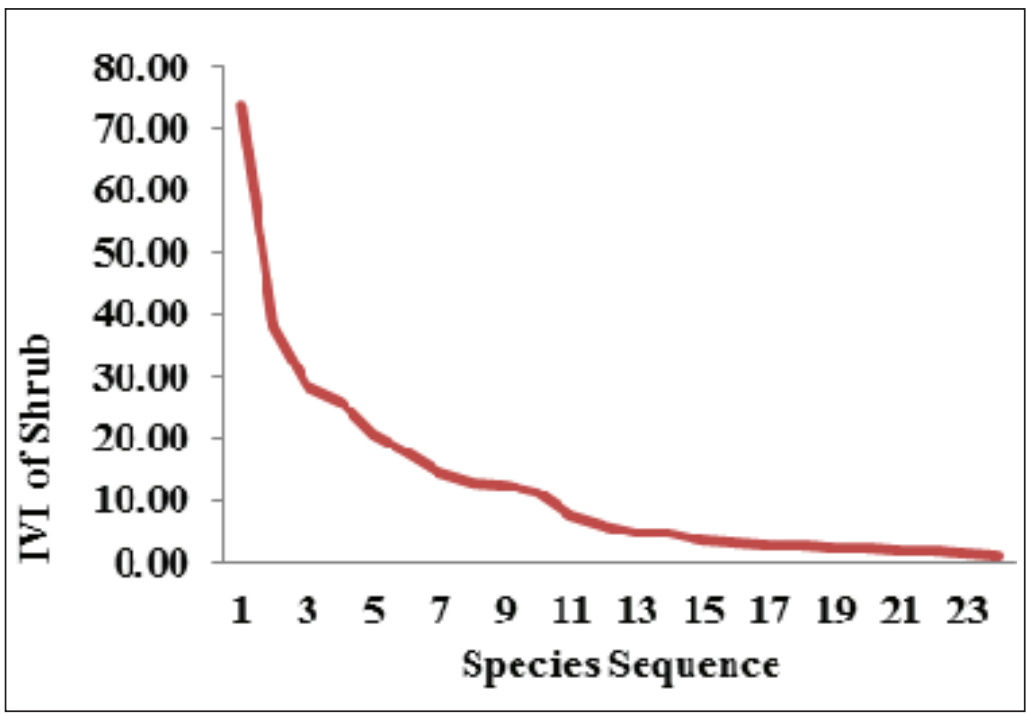

FIG. 4. Dominance-diversity curve of herbs.

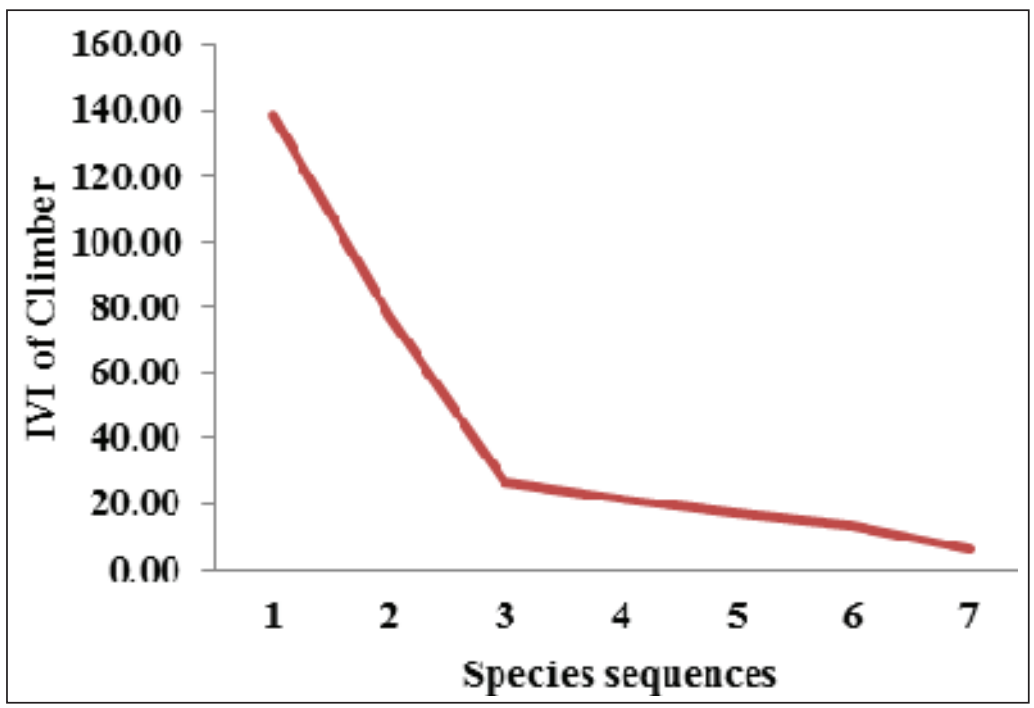

FIG. 5. Dominance-diversity curve of climbers.

In this study, Shannon Weiner's diversity index of the forest was found maximum of herbs followed by shrubs and trees. Similarly, Evenness Index was high in shrubs. The study of Index of dominance showed that climbers had maximum value, followed by trees and shrubs and minimum of herbs. 
TABLE 2. Diversity, evenness and Dominance Index in BBZCF.

\begin{tabular}{|l|l|l|l|l|}
\hline Indexllife forms & Tree & Shrub & Herb & Climber \\
\hline Diversity index & 1.63 & 2.01 & 2.31 & 1.1 \\
\hline Evenness index & 0.47 & 0.63 & 0.6 & 0.57 \\
\hline Dominance & 0.4 & 0.23 & 0.16 & 0.43 \\
\hline
\end{tabular}

\section{Utilities of NTFPs}

Of the total of 109 NTFPs species found in the forest, they were categorized into 14 groups on the basis of their use. Same plants were also used for a number of purposes. The plant use categorizations with number of plants used is shown in table 3.

TABLE 3. NTFPs utilization categorization.

\begin{tabular}{|c|c|c|c|}
\hline S.N. & Use types & No. of species & Remarks \\
\hline 1. & Medicine & 100 & \\
\hline 2. & Fodder & 86 & \\
\hline 3. & Food & 47 & $\begin{array}{l}\text { Vegetable-20, fruit-19, pickle-9, } \\
\text { spices-5, Seed-4 }\end{array}$ \\
\hline 4. & Veterinary medicine & 26 & \\
\hline 5. & Dying and tannin & 19 & Dying-10, tanning-13 \\
\hline 6. & Utensils and handicraft & 19 & $\begin{array}{l}\text { Utensil- } 14 \text {, dish plates and cups- } 5 \text {, } \\
\text { paper and pulps- } 4 \text {, pillows- } 2\end{array}$ \\
\hline 7. & Crop management & 17 & Fencing-7, manure-5, pesticides-5 \\
\hline 8. & Ornamental & 14 & \\
\hline 9. & Insecticides & 11 & \\
\hline 10. & Construction material & 9 & \\
\hline 11. & Beverage & 8 & \\
\hline 12. & Piscicidal & 8 & \\
\hline 13. & Religious & 7 & \\
\hline 14. & Miscellaneous & 10 & Exudates- 4, oil-4, bio-briquette-2 \\
\hline
\end{tabular}

As shown in fig. 6 and 7, The most frequently used plant parts were leaf ( 80 species), followed by whole plant ( 65 species). Most of species found in the forest were medicinally important. 
Medicinal plants were used in various forms for different ailments. Majority of the plants were used in the form of juice ( 73 species) followed by paste (69 species).

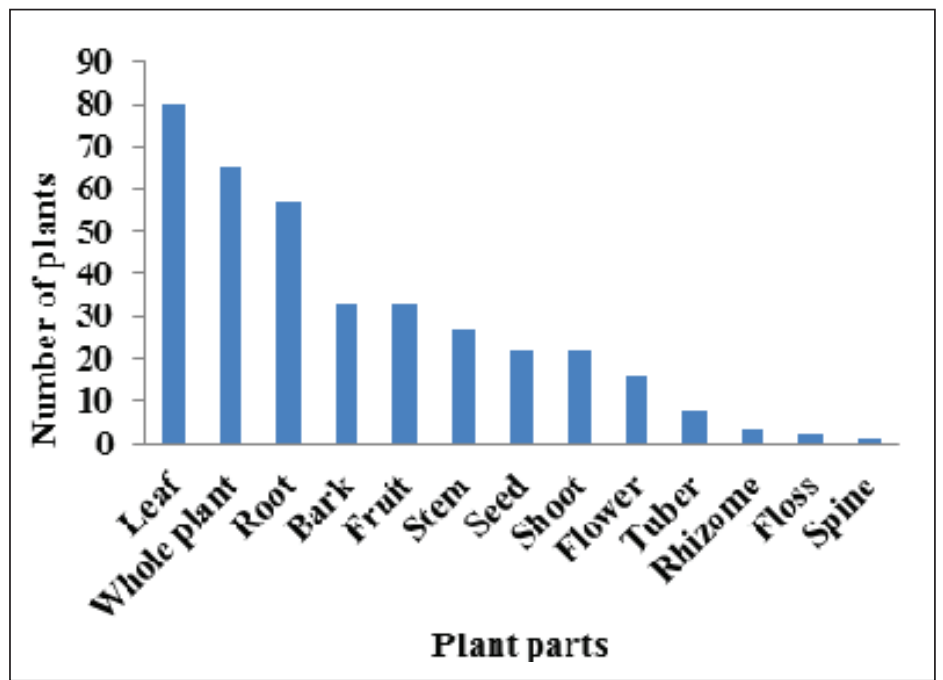

FIG. 6. Plant parts used.

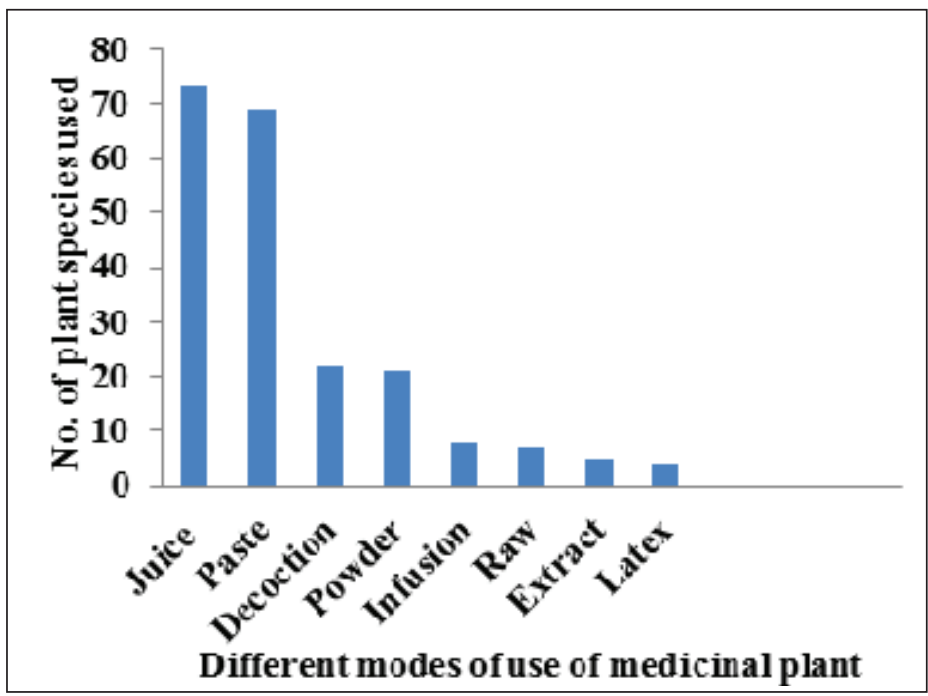

FIG.7. Different modes of use of medicinal plants.

The plants used to treat various diseases and ailments are grouped under 12 disease categories with the maximum number of species (67) being used for gastro-intestinal disorders and 67 for dermatological disorders (table 4). 
TABLE 4. Number of species used in different ailment category.

\begin{tabular}{|c|c|c|}
\hline Ailment category & Biomedical terms & $\begin{array}{c}\text { No. of } \\
\text { species used }\end{array}$ \\
\hline $\begin{array}{l}\text { Gastro-intestinal } \\
\text { disorders }\end{array}$ & $\begin{array}{l}\text { Constipation, Diarrhea, Dysentery, Nausea, } \\
\text { Indigestion, Vomiting, Stomachache, Gastric } \\
\text { trouble, Loss of appetite, Intestinal worms, Colic } \\
\text { pain, Flatulence, Piles }\end{array}$ & 67 \\
\hline $\begin{array}{l}\text { Dermatological } \\
\text { disorders }\end{array}$ & $\begin{array}{l}\text { Cuts, Wounds, Boils, Pimples, Skin rashes, } \\
\text { Ringworm, Scabies, Leprosy, Skin burns, Skin } \\
\text { blemishes, Ecto-parasites, Skin diseases, Hair } \\
\text { problems, Body inflammation }\end{array}$ & 67 \\
\hline Fevers, & Ordinary fever, Diaphoretic Malaria, Typhoid & 42 \\
\hline $\begin{array}{l}\text { skeleto-muscular } \\
\text { pain and swelling }\end{array}$ & $\begin{array}{l}\text { Body ache, Muscular pain, Sprain, Strain, } \\
\text { Rheumatism, Arthritis, Joint pain, Swelling }\end{array}$ & 33 \\
\hline Respiratory diseases & $\begin{array}{l}\text { Common cold, Cough, Asthma, Bronchitis, Chest } \\
\text { pain, Lung disorders }\end{array}$ & 32 \\
\hline $\begin{array}{l}\text { Ear, nose, throat } \\
\text { problems }\end{array}$ & Earache, Throat sore, Nose bleeding, Sinusitis. & 30 \\
\hline $\begin{array}{l}\text { Ureno-genital } \\
\text { problems }\end{array}$ & $\begin{array}{l}\text { Sexual debility, Infertility, Leucorrhoea, } \\
\text { Gonorrhea, Menstrual disorders, Frequent } \\
\text { urination, Diuretic, Aphrodisiac }\end{array}$ & 28 \\
\hline Headache & Migraine Headache, Normal Headache & 16 \\
\hline $\begin{array}{l}\text { Oral and dental } \\
\text { disorder }\end{array}$ & Toothache, Mouth sore & 15 \\
\hline $\begin{array}{l}\text { Cardio-vascular } \\
\text { disorder }\end{array}$ & Cardiac, Blood pressure & 6 \\
\hline Mental disorder & Mental tonic, Memory tonic, Epilepsy & 4 \\
\hline Others & $\begin{array}{l}\text { Fracture, Tonic, Lactation, Easy delivery, Tumor, } \\
\text { Diabetes, Cooling agent, Stimulant and Eye } \\
\text { problem }\end{array}$ & 29 \\
\hline
\end{tabular}

\section{Matrix preference ranking}

Among 109 NTFPs species found, 10 prioritized species were selected through key informant survey based on various criteria in the preference matrix. Calamus tenuis got the maximum score and was placed in the first rank followed by Curcuma longa, Piper longum, Phyllanthus emblica, Asparagus racemosus, Terminalia bellirica, Terminalia chebula, Bauhinia variegata, Tinospora sinensis and Dryopteris cochleata respectively.

The data from inventory revealed that herbaceous plants stand out as richest life form of NTFPs in comparison to trees, shrubs and climbers. Chhetri (1997) also found higher number of herbs species than shrubs in Chitwan National Park. Trewia nudiflora, Clerodendrum 
viscosum, Imperata cylindrica and Mikania micrantha were dominant species among trees, shrubs, herbs and climbers respectively on the basis of IVI values which express the dominance and ecological success of the species (Misra, 1968) and removal of these species might result in important change in biotic community. Acacia catechu and Bombax ceiba were listed as a commercially threatened species in IUCN category and as protected species under Forest Act 1993, banned for transportation, export and felling. Similarly, Alstonia scholaris fall under rare list of IUCN and as Vulnerable in CAMP (Shrestha \& Joshi, 1996). Asparagus racemosa, Piper longum and Tinospora sinensis are listed as Vulnerable in CAMP (Shrestha \& Joshi, 1996).

The user groups of BBZCF were found to possess a very rich ethnobotanical knowledge and had been making use of wild plant species for various purposes. Despite all the marvelous advancements in modern medicine in the industrialized part of the world, traditional herbal medicine had always been practiced by the local people of these rural areas. Guruwas and Kesuka are traditional healers in the community and had rich knowledge on medicinal plants, their mode of action and use.

The availability of high value as well as prioritized NTFPs in the forest such as Asparagus racemosus, Gaultheria fragrantissima, Phyllanthus emblica, Piper longum and Tinospora sinensis among 30 NTFPs enlisted by GoN/MoFSC (2007) had made more promising opportunities for CFUGs to undertake NTFPs as income generating prospect. People were more interested in NTFPs which could give quick return and; have potential market and ease of propagation was also important factors. From the forest, annual amount of Rs. 27,776 and Rs. 53, 880 were generated by trading Curcuma longa and Calamus tenuis respectively (BBZCF, 2013). Till date no strong efforts had been done in terms of NTFPs in this community forest despite of its potentiality. So emphasis should be given NTFPs cultivation with high economic potential suited to biophysical condition of forest and have no negative impacts on environment.

Altogether, 109 NTFPs were recorded in BBZCF in which diverse life forms were of herbs followed by shrubs, trees and climbers. Most dominant species was Trewia nudiflora among trees; Clerodendrum viscosum among shrubs; Imperata cylindrica among herbs and Mikania micrantha among climbers. The CFUs were using NTFPs for medicinal, fodder, food, dying and tannin, utensils and handicrafts, crop management, ornamentals, insecticides, construction material, beverage, piscicidal, religious and for miscellaneous purposes. From matrix preference ranking, Calamus tenuis was found the most preferred NTFPs in the study area. Emphasis should be given to these NTFPs with high economic potential which is also suited to biophysical condition of forest.

\section{ACKNOWLEDGEMENTS}

Our deep appreciation goes to Dr. Harka Gurung - New ERA Fellowship 2013 and University Grants Commission Research Grant 2013 for financial support. We express thanks to DNPWC and Mr. Bhuwaneswar Prasad Chaudhary, President of BBZCF for granting permission to conduct this work. Thanks to Kiran Bhusal, Bijay Maharjan, Sandhya Manandhar and Sabina Twanabasu who helped during the field work. All the respondents of BBZCF Users group are acknowledged for their valuable time and information. 


\section{REFERENCES}

ARKIN, H R; COLTON, R (1963) Tables for statisticians. Barnes \& Noble, New York, USA.

BBZCF (2013) Operational plan. Baghmara Buffer Zone Community Forest, Mrigakunj Users Group, Bachhauli, Chitwan, Nepal.

CHHETRI, U J (1997) Vegetation analysis and natural regeneration status of a protected Terai mixed sal (Shorea robusta) forest (Chitwan National Park). M. Sc. dissertation, Central Department of Botany, Tribhuvan University, Kathmandu, Nepal.

FAO (1995) Non-wood forest products for rural income and sustainable forestry. NWFPs, Food and Agriculture Organisation, Rome, Italy.

FAO (1999). FAO forestry - Towards a harmonised definition of non-wood forest products. Available at http://www.fao.org/docrep/x2450e/x2450e0d.htm.

KESHARI, V P (2007) Promotion and trade of tropical NTFPs in central Terai of Nepal. Available at http:// www.forestrynepal.org/images/Promotion $\% 20$ and $\% 20$ Trade $\% 20$ of\%20Tropical\%20NTFPs $\% 20$ in $\% 20$ Central\%20Terai\%20of\%20Nepal.pdf.

KHANAL, L M (2006) Non-timber forest products (NTFPs) use in two villages in Lumbini zone of Nepal, M. Sc. Dissertation, University of Natural Resources and Applied Life Sciences, Vienna, Austria.

MAGAR, D B (2008) Contribution of non-timber forest products in the livelihood of Chepang community. A final report submitted to Social Inclusion Research Fund, SNV, Lalitpur, Nepal.

MFSC (2004) Community forestry inventory guideline (Revised). Community Forestry Division, Ministry of Forest and Soil Conservation (MFSC), Kathmandu, Nepal.

MFSC (2007) Jaributikheti Prasar Pustika. Government of Nepal, Ministry of Forest and Soil Conservation (MFSC), Department of Forests, Babarmahal, Kathmandu, Nepal (in Nepali).

MISHRA, R (1968) Ecology workbook. Oxford \& IBH Publishing Company, New Delhi, India.

OJHA, H R; SUBEDI, B P ; DANGAL, S P; (2003) Management of non-timber forest products: Recent innovations in resource assessment and sustainable harvesting. The Nepal Journal of Forestry XII (2): $55-65$.

PRESS, J R; SHRESTHA, K K; SUTTON, D A (2000) Annotated checklist of the flowering plants of Nepal. The Natural History Museum, London, UK.

PRESTON, F W (1948) The commonness and rarity of species. Ecology 29(3): 254-283.

SHARMA, B K; CHALISE, M K; SOLANKI, G S (2012) Vegetation types and wildlife occurrence in Baghmara Buffer Zone Community Forest. International Multidisciplinary Research Journal 2: 52-65.

SHRESTHA, T B; JOSHI, R M (1996) Rare, endemic and endangered plants of Nepal. WWF Nepal Program, Kathmandu, Nepal.

THAKUR, R B (2005) Assessment of non timber forest products for enterprise development (a case study from government managed forest of hosrandi and uram Pokhara VDCs of Parvat district). B.Sc. thesis, Institute of Forestry, Tribhuvan University, Pokhara, Nepal. 